\title{
Comparative study on growth and yield performance of oyster mushroom (Pleurotus florida) on different substrates
}

\author{
S. R. Mondal, M. J. Rehana, M. S. Noman and S. K. Adhikary \\ Agrotechnology Discipline, Khulna University, Khulna-9208, Bangladesh
}

\begin{abstract}
Experiment was carried out in the mushroom cultivation laboratory, Horticulture Center, Khairtala, Jessore to evaluate the better performance of oyster mushroom Pleurotus florida in different substrate compositions as well as to find out the better substrate for mushroom cultivation. Highest mycelium running rate was found in banana leaves and rice straw (1:1) but the lowest in control. Completion of mycelium running time was lowest in banana leaves and rice straw (1:3 and 3:1). Number of total primordia and effective primordia, found highest in control but the maximum pileus thickness was measured from rice straw. Highest biological yield and economic yield (164.4 g and $151.1 \mathrm{~g}$ ) was obtained from rice straw which was much higher than control. From the graphical view, both positive and negative relationships were found between economic yield and different yield contributing attributes.
\end{abstract}

Keywords: Banana leaves, Rice straw, Growth, Yield and Pleurotus florida

\section{Introduction}

Mushrooms are one kind of edible fungi belonging to the genus Pleurotus under the class Basidiomycetes. Oyster mushroom (Pleurotus florida) is an edible mushroom having excellent flavor and taste. The quality of the waste product (rice straw) is improved due to the degradation of cellulose and hemicellulose by mushroom enzymes and hence has been rendered more digestible. Thus rice straw is transformed to a valuable roughage and mushrooms provide an additional income without an extension of the limited acreage. (Mueller and Cantner, 1990). Comparing rice straw with wheat straw, rice straw yielded about $10 \%$ more mushroom than wheat straw under the same cultivation conditions (Zhang et al., 2002). Mushroom substrate may be defined as a kind of ligno cellulose material which supports the growth, development and fruiting of mushroom (Chang and Miles, 1988). Oyster mushroom may be grown on wide range of plant waste as substrate e.g. sawdust, paddy straw, sugarcane baggage, corn stalk, corn cobs, waste cotton, leaves and pseudo stem of banana, water hyacinth, duck weed, rice straw etc. does not require costly processing method and enrichment material (Quimio, 1980; Chow, 1980; Bano et al., 1979). However the experiment was conducted on rice straw and banana leaves at various compositions with a view to determine the cheapest substrate with best yield performance.

\section{Materials and Methods}

The experiment was conducted in the Laboratory of Horticulture Centre cum Mushroom Sub Centre, Department of Agricultural Extension (DAE), Khairtala, Jessore during the months of October, 2008 to January, 2009.

Preparation of pure culture: To obtain pure culture, PDA culture or tissue culture planting method was used. The PDA media was prepared by using of $250 \mathrm{~g}$ peeled and sliced potato, $20 \mathrm{~g}$ dextrose, $30 \mathrm{~g}$ agar and $250 \mathrm{mg}$ aspergine in one liter of water. About $5 \mathrm{ml}$ of PDA mixture was poured in each test tube followed by plugging. The media was sterilized in an autoclave for 15 minutes at $121^{\circ} \mathrm{C}$ with $1.5 \mathrm{~kg} / \mathrm{cm}^{2}$ pressure. The sterilized PDA containing test tube was kept in a slanting position. The mushroom was thoroughly pre-washed in distilled water. A scalpel was then dipped in alcohol and flamed until it was redhot. Then it was cooled for 10 seconds. The cut was made length wise from the cap to down wards. Small piece of the internal tissue of the broken mushroom was cut and removed with a flamed needle. The needle with the tissue attached was then immediately inserted in to test tube slant and the tissue laid on the agar surface. The mouth of the test tube was flamed before the needle was inserted. The mouth of the test-tube was plugged with cotton plug. After 3 to 4 days, the tissue was covered with a white mycelium that was spread on the agar surface. 
Preparation of mother culture: The mother culture substrate was prepared by using good quality wheat grains and $\mathrm{CaCO}_{3}$ and packed tightly in $25 \times 18 \mathrm{~cm}$ polypropylene (pp) bag. These packets were sterilized in an autoclave for one hour at $121^{\circ} \mathrm{C}$ and $1.5 \mathrm{~kg} / \mathrm{cm}^{2}$ atmospheric pressure and then these were kept 24 hours for cooling. Then a piece of pure culture measured $1 \times 1 \mathrm{~cm}^{2}$ was placed aseptically into the mouth of the each mother culture packet and the packets were placed in the growth chamber at $25 \pm 1^{\circ} \mathrm{C}$ in dark place. After 15 to 20 days the mother culture became white due to complete the mycelium running and then it was ready for inoculating spawn packets.

Preparation of desired spawn packet: For the growth of Pleurotus florida six different substrates with a control were used. These are as follows:

\begin{tabular}{|c|c|l|}
\hline SI. no & Substrates & Composition \\
\hline 1 & Substrate-1 & Banana leaves \\
\hline 2 & Substrate-2 & Rice straw \\
\hline 3 & Substrate-3 & Banana leaves : rice straw = 1: 3 \\
\hline 4 & Substrate-4 & Banana leaves : rice straw = 1: 1 \\
\hline 5 & Substrate-5 & Banana leaves : rice straw = 3: 1 \\
\hline 6 & Control * & Sawdust: wheat bran: rice husk $=8: 4: 1$ \\
\hline
\end{tabular}

* Standard practice followed in the NMDEC and its relevant 6 substrates.

Preparation of banana leaves: The banana leaves was fragmented into small pieces (less than three centimeter particle size) after sun dried with a sickle. The substrate consisted of banana leaves was not supplemented.

Preparation of rice straw: After sun drying, rice straw was fragmented into small pieces (less than three centimeter particle size) with a sickle. The substrate consisted of rice straw was not supplemented.

The materials were mixed thoroughly with mixture machine and the moisture was increased by adding water until it reached around $65 \%$ moisture content. Then polypropylene bags $(25 \times 18 \mathrm{~cm})$ were filled with $500 \mathrm{~g}$ prepared substrate and packed tightly. A hole of 3 to $5 \mathrm{~cm}$ was made with pointed steel at the centre for space to put the inoculums. The packets were plugged with cotton and bind with rubber band to prevent the displacement of brown paper. The packets were sterilized in the autoclave for 15 minutes at $120^{\circ} \mathrm{C}$ with $1.5 \mathrm{~kg} / \mathrm{cm}^{2}$ atmospheric pressure and were kept 24 hours for cooling. One teaspoonful of mother culture materials containing mycelia was placed aseptically through the hole of each packet separately and each treatment was replicated 4 times. The packets were then marked treatment wise with a marker pen and were kept on the self in an incubation room at $25 \pm 1{ }^{\circ} \mathrm{C}$ under $80 \%$ to $85 \%$ relative humidity and were allowed to complete the whitish mycelial growth.

Culture of spawn packet: After completion of the spawn-run in the substrate the cotton plug, brown paper and rubber band from the mouth of spawn packet were removed and the mouth of each packet was wrapped tightly with rubber band. Two ends opposite to each other of the upper position of bags were opened with a blade by removing the plastic sheet in "D" shape after which the opened surface of the substrate was scraped slightly with a teaspoon for removing the thin whitish mycelial layer. Then the spawn packets were soaked in water for 10 minutes. After that the packets were kept on the plastic tray for removing excess water. The spawn packets were placed according to experimental design on the shelf and covered with gunny bag with proper ventilation. Water was sprinkled on the D-shaped cut of spawn packet and on gunny bag whenever necessary to maintain $80-85 \%$ relative humidity. Water spraying was done twice a day until the mushrooms were matured enough to be harvested. Temperature (ranges $22^{\circ} \mathrm{C}$ to $27^{\circ} \mathrm{C}$ ), high relative humidity $(80-85 \%)$ and proper ventilation at culture room were maintained for the development of fruiting body. 
Data collection and statistical analysis: The experiment was laid out in Completely Randomized Design (CRD) with five treatments and a control with four replications. The data were recorded on mycelium running rate in spawn packet, Time required for completion of mycelium running, time required for primordia initiation, time required for harvesting, number of primordia, number of effective fruiting body, stalk length, stalk diameter, pileus diameter, pileus thickness, average individual weight of fruiting body, biological yield, economic yield, harvest index. The data were analyzed by MSTAT-C programme. The treatment means were compared using Duncan's Multiple Range Test i.e. DMRT (Gomez and Gomez, 1984).

\section{Results and Discussion}

Mycelium running rate: Mycelium running rate (MRR) in spawn packet ranged from 0.5048 to 0.7875 $\mathrm{cm} /$ day. The highest mycelium running rate was observed on banana leaves \& rice straw (1:1) which was statistically similar to banana leaves, banana leaves \& rice straw (1:3). The lowest mycelium running rate was recorded on control which was statistically similar with banana leaves \& rice straw (3:1) (Table 1). The presence of right proportion of alpha-cellulose, hemicellulose and lignin was the probable cause of higher rate of mycelium running in banana leaves and rice straw. The substrate, saw dust resulted the lowest mycelium running rate might be due to presence of different kinds of polyphenolic substances in them as suggested by Wang (1982) and low content of cellulose (Gohl, 1993). Suitable C: N ratio might be responsible for the higher mycelial growth in banana leaves and rice straw. Quimio and Sardsud (1981) supported the results, who found that the optimum carbon /nitrogen ratio for mycelial growth of $P$. ostratus was ranged from 40:1 to 90:1.

Table 1. Effect of different substrates on mycelial growth of oyster mushroom

\begin{tabular}{|l|c|c|}
\hline Substrates & $\begin{array}{c}\text { Mycelium running rate in } \\
\text { spawn packet (cm/day) }\end{array}$ & $\begin{array}{c}\text { Time required for completion } \\
\text { of mycelium running (days) }\end{array}$ \\
\hline Banana leaves & $0.7425 \mathrm{ab}$ & $21.00 \mathrm{~d}$ \\
\hline Rice straw & $0.6747 \mathrm{~b}$ & $24.25 \mathrm{~b}$ \\
\hline Banana leaves and Rice straw (1:3) & $0.7125 \mathrm{ab}$ & $21.00 \mathrm{~d}$ \\
\hline Banana leaves and Rice straw (1:1) & $0.7875 \mathrm{a}$ & $22.00 \mathrm{c}$ \\
\hline Banana leaves and Rice straw (3:1) & $0.5775 \mathrm{c}$ & $21.00 \mathrm{~d}$ \\
\hline Saw dust (Control) & $0.5048 \mathrm{c}$ & $24.75 \mathrm{a}$ \\
\hline Significance & $\star \star *$ & 2.48 \\
\hline CV (\%) & 6.01 & \\
\hline
\end{tabular}

Time (days) required for completion of mycelium running: Days to complete mycelium running in spawn packet ranged 21.00 days to 24.75 days on different substrates (Table 1 ). Significantly the lowest days to complete mycelium running was recorded on banana leaves \& rice straw (3:1), banana leaves and banana leaves \& rice straw (1:3). Highest day was required to complete mycelium running on control, which was significantly different from other substrates (Table 1). The appreciable days to complete mycelium running of oyster mushroom on different substrates might be due to variation in their chemical composition and C: $\mathrm{N}$ ratio as reported by Bhatti et al. (1987). The results recorded on all substrates were almost similar to the findings of Shah et al. (2004). He reported that the spawn running took 16-25 days after inoculation. Similar results also reported by Tan (1981).

Time required for primordia initiation: The lowest time (5.50 days) for primordia initiation recorded on control which was statistically similar with banana leaves \& rice straw in both (1:3) and (3:1) ratio. The highest time for primordia initiation was found in rice straw (Table 2). Shah et al., 2004 found that the spawn heads appeared 6 days after the spawn running. Ahmed (1998) stated that $P$. ostreatus completed spawn running in 17-20 days on different substrates and time for pinhead formation was noted at 23-27 days. 
Table 2. Effect of different substrates on time required for primordia initiation and time required for harvesting

\begin{tabular}{|l|c|c|}
\hline Substrates & $\begin{array}{c}\text { Time required for primordia } \\
\text { initiation (days) }\end{array}$ & $\begin{array}{c}\text { Time required for } \\
\text { harvesting (days) }\end{array}$ \\
\hline Banana leaves & $6.50 \mathrm{~b}$ & $10.50 \mathrm{ab}$ \\
\hline Rice straw & $8.00 \mathrm{a}$ & $11.00 \mathrm{a}$ \\
\hline Banana leaves and Rice straw (1:3) & $6.25 \mathrm{bc}$ & $9.25 \mathrm{~b}$ \\
\hline Banana leaves and Rice straw (1:1) & $7.50 \mathrm{a}$ & $11.25 \mathrm{a}$ \\
\hline Banana leaves and Rice straw (3:1) & $6.00 \mathrm{bc}$ & $10.50 \mathrm{ab}$ \\
\hline Sawdust (Control) & $5.50 \mathrm{c}$ & $6.75 \mathrm{c}$ \\
\hline Significance & $\star \star$ & $\star \star$ \\
\hline CV (\%) & 6.89 & 5.97 \\
\hline
\end{tabular}

Time required for harvesting: The lowest time for harvesting was recorded from control. The highest day was required for first harvest on banana leaves and rice straw substrate (1:1) (Table 2). The result of present experiment are in agreement with the findings of Bugarski et al., (1994) who found that the first fruiting occurred on different days depending on substrates.

Number of total primordia: In case of $1^{\text {st }}$ flush number of total primordia ranged from 11.75 to 44.25 and the maximum number of primordia was recorded on sawdust. The minimum number of total primordia was recorded on banana leaves and rice straw (1:1) which was statistically similar with banana leaves and banana leaves \& rice straw (3:1) (Table 3). On the other hand in $2^{\text {nd }}$ flush no. of total primordia was found maximum (52.25) on sawdust. The minimum number (19.5) of total primordia was recorded on banana leaves. In the $3^{\text {rd }}$ flush number of total primordia ranged from 15.50 to 40.25 and the maximum number was recorded on rice straw which was statistically similar with sawdust. The lowest number was recorded on banana leaves \& rice straw (1:1). From the result it can be said that the highest number (52.25) of total primordia was recorded in $2^{\text {nd }}$ flush on control and the lowest number (11.75) was recorded in first flush on banana leaves \& rice straw (1:1) (Table 3).

Table 3. Number of primordia and effective fruiting body as affected by different substrates

\begin{tabular}{|l|c|c|c|c|c|c|}
\hline \multirow{2}{*}{ Substrates } & \multicolumn{3}{|c|}{ No. of total primordia } & \multicolumn{3}{c|}{ No. of effective fruiting body } \\
\cline { 2 - 7 } & $1^{\text {st }}$ flush & $2^{\text {nd }}$ flush & $3^{\text {rd }}$ flush & $1^{\text {st }}$ flush & $2^{\text {nd }}$ flush & $3^{\text {rd }}$ flush \\
\hline Banana leaves & $13.00 \mathrm{~d}$ & $19.50 \mathrm{~b}$ & $18.75 \mathrm{c}$ & $8.50 \mathrm{~d}$ & $12.75 \mathrm{c}$ & $8.0 \mathrm{~cd}$ \\
\hline Rice straw & $30.50 \mathrm{c}$ & $45.25 \mathrm{a}$ & $40.25 \mathrm{a}$ & $24.00 \mathrm{c}$ & $37.00 \mathrm{a}$ & $26.0 \mathrm{a}$ \\
\hline Banana leaves and Rice straw (1:3) & $36.00 \mathrm{~b}$ & $24.25 \mathrm{~b}$ & $22.50 \mathrm{~b}$ & $27.50 \mathrm{~b}$ & $19.00 \mathrm{~b}$ & $9.5 \mathrm{c}$ \\
\hline Banana leaves and Rice straw (1:1) & $11.75 \mathrm{~d}$ & $24.50 \mathrm{~b}$ & $15.50 \mathrm{~d}$ & $9.00 \mathrm{~d}$ & $19.75 \mathrm{~b}$ & $6.75 \mathrm{~d}$ \\
\hline Banana leaves and Rice straw (3:1) & $14.00 \mathrm{~d}$ & $26.25 \mathrm{~b}$ & $26.00 \mathrm{~b}$ & $10.50 \mathrm{~d}$ & $20.00 \mathrm{~b}$ & $10.5 \mathrm{c}$ \\
\hline Sawdust (Control) & $44.25 \mathrm{a}$ & $52.25 \mathrm{a}$ & $37.75 \mathrm{a}$ & $37.25 \mathrm{a}$ & $21.25 \mathrm{~b}$ & $17.25 \mathrm{~b}$ \\
\hline Significance & $\star \star$ & $\star \star$ & $\star \star$ & $\star \star$ & $* \star$ & $\star \star$ \\
\hline CV (\%) & 7.71 & 10.85 & 9.77 & 7.04 & 5.58 & 9.77 \\
\hline
\end{tabular}

Number of effective fruiting body: Effective fruiting body is the edible part of mushroom. There was significant variability on different substrates under this study (Table 3 ). In case of $1^{\text {st }}$ flush number of effective fruiting body ranged from 8.5 to 37.25 and the maximum number of effective fruiting body was recorded on sawdust. The minimum number of effective fruiting body was recorded on banana leaves. In case of $2^{\text {nd }}$ flush number of effective fruiting body was recorded maximum (37.0) on rice straw. The minimum number (12.75) was recorded on banana leaves. In $3^{\text {rd }}$ flush, the number of effective fruiting body ranged from 6.75 to 26.0 and the maximum number was recorded on rice straw and minimum number was recorded on banana leaves \& rice straw (1:1). Higher number of effective fruiting body might happen due to the presence of glucose, fructose and trehalose in the substrate, reported by Kitamoto et al (1995). Poppe (1973) found that Indole Acetic Acid (IAA) increased the number of fruiting body of mushroom. 
Stalk length: Length of the stalk of $P$. florida was differed on different substrates at $1 \%$ level of significance. In case of $1^{\text {st }}$ flush highest stalk length was recorded on sawdust which was statistically similar with rice straw, banana leaves \& rice straw (1:3) and banana leaves \& rice straw (3:1). The lowest stalk length was recorded on banana leaves \& rice straw (1:1), which was statistically similar with banana leaves (Table 4$)$. On the other hand in $2^{\text {nd }}$ flush the maximum was recorded on banana leaves \& rice straw (1:1). In $3^{\text {rd }}$ flush the maximum was recorded on sawdust and minimum length was recorded on rice straw. Among the three flushes, the highest stalk length $(3.8 \mathrm{~cm})$ was found in sawdust of first flush and the lowest $(1.64 \mathrm{~cm})$ was found in rice straw of third flush (Table 4). The quality of oyster mushroom $P$. florida depends on the length of stalk, the higher the length of stalk, the poor the quality of mushroom (Zadrazil, 1978).

Table 4. Effect of different substrates on some yield attributes of oyster mushroom

\begin{tabular}{|c|c|c|c|c|c|c|c|c|c|}
\hline \multirow[t]{2}{*}{ Substrates } & \multicolumn{3}{|c|}{ Stalk length (cm) } & \multicolumn{3}{|c|}{ Pileus diameter $(\mathrm{cm})$} & \multicolumn{3}{|c|}{ Pileus thickness (cm) } \\
\hline & $\begin{array}{l}1^{\text {st }} \\
\text { flush }\end{array}$ & $\begin{array}{l}2^{\text {nd̆ }} \\
\text { flush }\end{array}$ & $\begin{array}{l}3^{\text {rd }} \\
\text { flush }\end{array}$ & $\begin{array}{l}1^{\text {st }} \\
\text { flush }\end{array}$ & $\begin{array}{l}2^{\text {nd }} \\
\text { flush }\end{array}$ & $\begin{array}{l}3^{\text {rd }} \\
\text { flush }\end{array}$ & $\begin{array}{l}1^{\text {st }} \\
\text { flush }\end{array}$ & $\begin{array}{l}2^{\text {nd }} \\
\text { flush }\end{array}$ & $\begin{array}{l}3^{\text {rd }} \\
\text { flush }\end{array}$ \\
\hline Banana leaves & $2.59 \mathrm{bc}$ & $2.30 \mathrm{~d}$ & $1.90 \mathrm{~b}$ & $4.48 \mathrm{bc}$ & $3.74 \mathrm{c}$ & $3.35 b$ & $0.547 b$ & $0.62 \mathrm{a}$ & $0.64 a$ \\
\hline Rice straw & $3.35 a b$ & $2.83 \mathrm{c}$ & $1.64 \mathrm{~b}$ & $4.79 \mathrm{~b}$ & $3.99 \mathrm{c}$ & $3.47 b$ & $0.57 \mathrm{ab}$ & $0.64 a$ & $0.66 a$ \\
\hline $\begin{array}{l}\text { Banana leaves \& Rice straw } \\
(1: 3)\end{array}$ & 3.31ab & $2.54 \mathrm{~cd}$ & $2.98 a$ & $4.13 c$ & $4.14 \mathrm{bc}$ & $3.11 b$ & $0.56 a b$ & $0.62 a$ & $0.54 b$ \\
\hline $\begin{array}{l}\text { Banana leaves \& Rice straw } \\
(1: 1)\end{array}$ & $2.47 c$ & $3.71 \mathrm{a}$ & $2.93 a$ & $4.89 \mathrm{~b}$ & $4.45 a b$ & $4.36 a$ & $0.64 a b$ & $0.43 b$ & $0.62 a$ \\
\hline $\begin{array}{l}\text { Banana leaves \& Rice straw } \\
(3: 1)\end{array}$ & $3.60 a$ & $2.65 \mathrm{~cd}$ & $2.93 a$ & $4.48 \mathrm{bc}$ & $3.70 \mathrm{c}$ & $4.36 a$ & $0.66 a$ & $0.58 a$ & $0.64 a$ \\
\hline Saw dust (Control) & $3.80 a$ & $3.32 b$ & $3.00 a$ & $7.79 a$ & $4.69 a$ & $3.35 b$ & $0.35 c$ & $0.49 b$ & $0.51 b$ \\
\hline Significance & 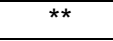 & *夫 & ** & *夫 & *夫 & ** & ** & *夫 & ** \\
\hline CV (\%) & 11.32 & 5.79 & 8.91 & 4.52 & 5.24 & 6.53 & 8.31 & 4.91 & 4.99 \\
\hline
\end{tabular}

Pileus diameter: Diameter of pileus differed on different substrates. In case of $1^{\text {st }}$ flush pileus diameter was found highest $(7.798 \mathrm{~cm})$ on sawdust and the lowest $(4.13 \mathrm{~cm})$ diameter was recorded on banana leaves \& rice straw (1:3). In $2^{\text {nd }}$ flush pileus diameter ranged from $3.709 \mathrm{~cm}$ to $4.698 \mathrm{~cm}$ (Table 4 ) and the maximum was recorded on sawdust. The minimum diameter was recorded on banana leaves \& rice straw (3:1). The highest $(4.36 \mathrm{~cm})$ pileus diameter on banana leaves \& rice straw (1:1) which was statistically similar with banana leaves \& rice straw $(3: 1)$ and the lowest $(3.11 \mathrm{~cm})$ pileus diameter was recorded on banana leaves \& rice straw (1:3) in $3^{\text {rd }}$ flush. From the result it can be said that the highest $(7.798 \mathrm{~cm})$ diameter was recorded on sawdust of $1^{\text {st }}$ flush and the lowest $(3.11 \mathrm{~cm})$ was recorded on banana leaves $\&$ rice straw (1:3) of $3^{\text {rd }}$ flush (Table 4). As the increases of pileus diameter the yield decreases, so in case of pileus diameter other substrates gave better results than control.

Pileus thickness: Thickness of pileus is one of the yields contributing character of mushroom. In case of $1^{\text {st }}$ flush pileus thickness ranged from $0.3560 \mathrm{~cm}$ to $0.6618 \mathrm{~cm}$ (Table 4) and the maximum was recorded on banana leaves and rice straw (3:1), which was statistically similar with rice straw, banana leaves and rice straw (1:3) and banana leaves and rice straw (1:1). The minimum was recorded on control. In case of $2^{\text {nd }}$ flush the maximum was recorded on rice straw. The lowest thickness was recorded on banana leaves and rice straw (1:1). Again in $3^{\text {rd }}$ flush the maximum was recorded on rice straw. The minimum pileus thickness was recorded on sawdust. From the result it can be said that the highest $(0.668 \mathrm{~cm})$ thickness was recorded on rice straw of $3^{\text {rd }}$ flush and the lowest $(0.3560 \mathrm{~cm})$ was recorded on sawdust of $1^{\text {st }}$ flash (Table 4). Here control gave poor result than other substrates and rice straw gave best result among the substrates. Pileus thickness may be higher due to the presence of adequate nutrient in the substrates. As it is a yield attributing character so the higher thickness of pileus may increase the yield.

Weight of individual fruiting body: In case of $1^{\text {st }}$ flush the maximum weight was recorded on rice straw and the minimum was recorded on sawdust (Table 5). On the other hand in $2^{\text {nd }}$ flush the highest was recorded on banana leaves and rice straw (1:1). The lowest was recorded on sawdust. In the $3^{\text {rd }}$ flush weight of individual fruiting body was found highest $(4.17 \mathrm{~g})$ on banana leaves and rice straw (3:1) and the lowest $(2.23 \mathrm{~g})$ weight was recorded on banana leaves and rice straw (1:3). 
Table 5. Effect of different substrates on weight of individual fruiting body, biological yield and economic yield

\begin{tabular}{|c|c|c|c|c|c|c|c|c|c|}
\hline \multirow[t]{2}{*}{ Substrates } & \multicolumn{3}{|c|}{$\begin{array}{l}\text { Weight of individual } \\
\text { fruiting body }(\mathrm{g})\end{array}$} & \multicolumn{3}{|c|}{ Biological yield $(\mathrm{g})$} & \multicolumn{3}{|c|}{ Economic yield $(\mathrm{g})$} \\
\hline & $\begin{array}{c}1^{\text {st }} \\
\text { flush }\end{array}$ & $\begin{array}{l}2^{\text {nd }} \\
\text { flush }\end{array}$ & $\begin{array}{l}3^{\text {rd }} \\
\text { flush }\end{array}$ & $\begin{array}{c}1^{\text {st }} \\
\text { flush }\end{array}$ & $\begin{array}{l}2^{\text {nd }} \\
\text { flush }\end{array}$ & $\begin{array}{l}3^{\text {rd }} \\
\text { flush }\end{array}$ & $\begin{array}{c}1^{\text {st }} \\
\text { flush }\end{array}$ & $\begin{array}{l}2^{\text {nd }} \\
\text { flush }\end{array}$ & $\begin{array}{c}3^{\text {rd }} \\
\text { flush }\end{array}$ \\
\hline Banana leaves & $5.32 \mathrm{bc}$ & $3.28 \mathrm{bc}$ & $3.36 b$ & $46.75 \mathrm{e}$ & $47.17 \mathrm{e}$ & $30.39 c$ & $44.11 \mathrm{e}$ & $42.28 d$ & $26.87 \mathrm{c}$ \\
\hline Rice straw & $6.41 \mathrm{a}$ & $4.32 a$ & $3.33 b$ & 159.3a & $164.4 a$ & $92.09 a$ & $149.4 a$ & $151.1 \mathrm{a}$ & $86.56 a$ \\
\hline Banana leaves \& Rice straw (1:3) & $4.70 \mathrm{c}$ & $3.68 b$ & $2.23 d$ & $134.5 b$ & $74.80 \mathrm{c}$ & $26.39 c$ & $127.3 b$ & $68.14 \mathrm{c}$ & $21.75 \mathrm{c}$ \\
\hline Banana leaves \& Rice straw (1:1) & $5.88 a b$ & $4.56 a$ & $3.58 \mathrm{~b}$ & $36.35 f$ & $93.42 b$ & $26.39 c$ & $33.17 f$ & $89.79 b$ & $22.75 \mathrm{c}$ \\
\hline Banana leaves \& Rice straw (3:1) & $6.02 \mathrm{ab}$ & $2.88 \mathrm{c}$ & $4.17 a$ & $58.54 d$ & $65.04 d$ & $48.50 \mathrm{~b}$ & $55.00 d$ & $59.67 d$ & $43.42 b$ \\
\hline Saw dust (Control) & $1.77 \mathrm{~d}$ & $2.84 \mathrm{c}$ & $2.77 \mathrm{c}$ & $85.13 c$ & $65.36 d$ & $48.12 b$ & $78.32 \mathrm{c}$ & $59.27 d$ & $43.07 b$ \\
\hline Significance & ** & ** & ** & ** & ** & ** & ** & ** & ** \\
\hline CV (\%) & 6.88 & 7.86 & 7.35 & 4.56 & 2.25 & 5.81 & 3.79 & 2.64 & 6.02 \\
\hline
\end{tabular}

Biological yield: Biological yield varied significantly due to effect of different substrates at different flushes. Maximum biological yield $(159.3 \mathrm{~g})$ was obtained from rice straw and the minimum biological yield (36.35 g) was obtained from banana leaves and rice straw (1:1) in the first flush. Rice straw produced highest biological yield $(164.49 \mathrm{~g})$ in case of second flush also. The lowest biological yield $(47.17 \mathrm{~g})$ was obtained from banana leaves which differ from rest of the substrates significantly in the same flush. In case of third flush again rice straw yielded maximum biological yield and minimum biological yield was obtained from banana leaves and rice straw both in 1:1 and 1:3 ratio (Table 5). From the overall result, it was found that rice straw yielded better than control. Obodai et al. (2003) evaluated eight lignocellulosic by-products as substrates for cultivation of the Oyster mushroom, Pleurotus ostreatus. The yields of mushroom on different substrates were $183.1 \mathrm{~g}, 151.8 \mathrm{~g}, 111.5 \mathrm{~g}, 87.8 \mathrm{~g}, 49.5 \mathrm{~g}$, $23.5 \mathrm{~g}, 13.0 \mathrm{~g}$ and $0.0 \mathrm{~g}$ for composted sawdust of Triplochiton scleroxylon, rice straw, banana leaves, maize stover, corn husk, rice husk, fresh sawdust and elephant grass respectively and rice straw give the best yield.

Economic yield: Economic yield is related to biological yield. In case of $1^{\text {st }}$ flush the maximum economic yield was recorded on rice straw. The minimum economic yield was recorded on banana leaves and rice straw (1:1), which was significantly lower than all other substrates. On the other hand in $2^{\text {nd }}$ flush economic yield ranged from $42.28 \mathrm{~g}$ to $151.1 \mathrm{~g}$ and highest was recorded on rice straw. The lowest economic yield was recorded on banana leaves. In the $3^{\text {rd }}$ flush economic yield was recorded maximum $(86.50 \mathrm{~g})$ on rice straw and the minimum $(21.75 \mathrm{~g})$ was recorded on banana leaves \& rice straw (1:3). From the result it was observed that the highest $(151.1 \mathrm{~g})$ economic yield was recorded in $2^{\text {nd }}$ flush on rice straw which was much higher than control and the lowest $(21.75 \mathrm{~g})$ was recorded on banana leaves $\&$ rice straw (1:3) in $3^{\text {rd }}$ flush.(Table 5). The highest yield on rice straw appeared to be due to comparatively better availability of nitrogen, carbon and minerals from this substrate (Shah et al., 2004).

\section{Relationship between yield attributes and economic yield}

A positive linear relationship was observed between economic yield and effective fruiting body (Fig. 3). This suggests that economic yield dependent on number of effective fruiting body and more than $69 \%$ $\left(R^{2}=0.699\right)$ of variation in the economic yield may be explained by variation of number of effective fruiting body. 


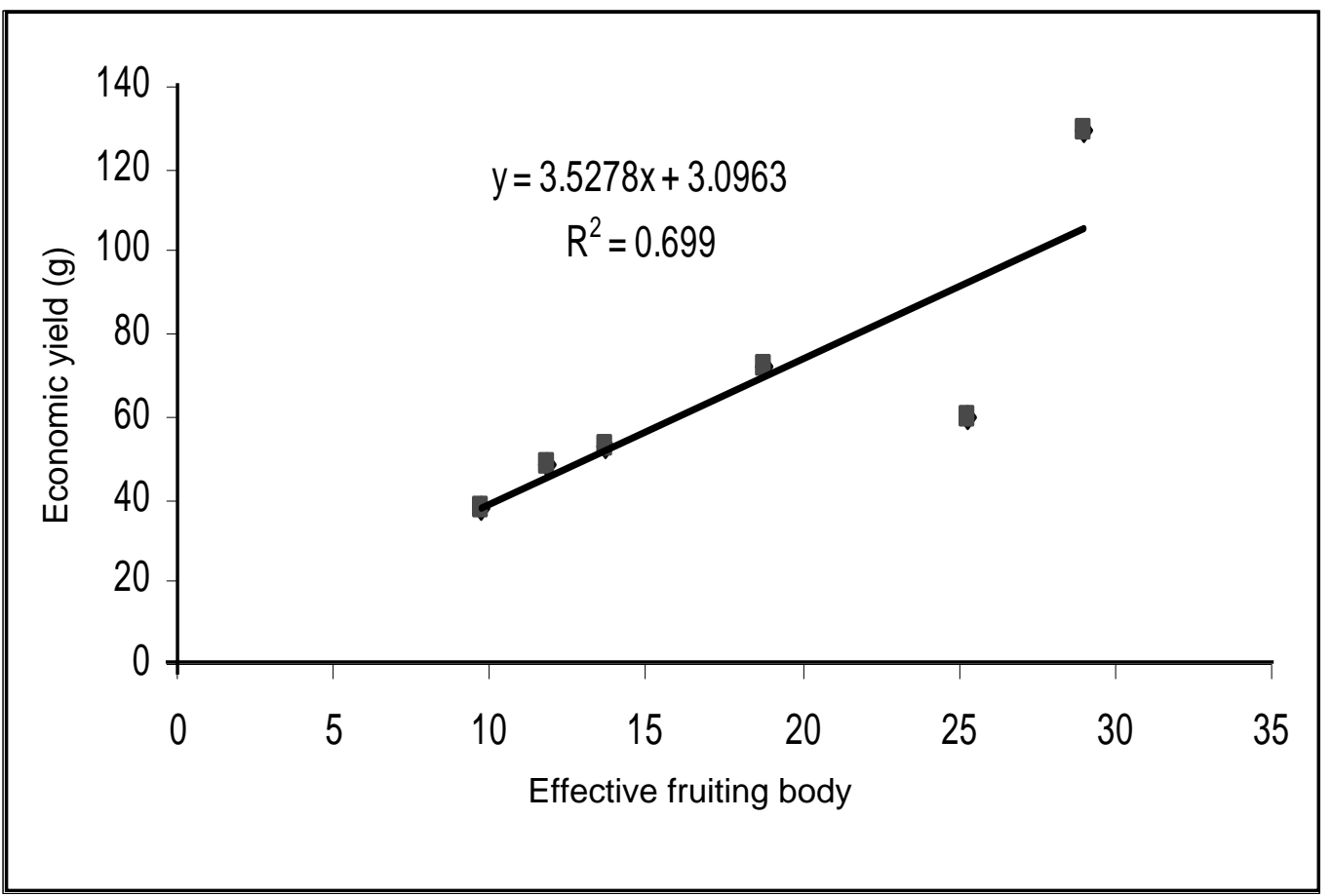

Fig.1. Functional relationship between effective fruiting body and economic yield

\section{References}

Ahmed, S. 1998. Development of mushroom varieties suitable for rural level in Bangladesh. Report presented in BARC Annual Review Programme. pp. 72-73.

Bano, Z., Nagaraja, N., Rajrathnam, S. and Pathwardhan, M.V. 1979. Cultivation of Pleurotus spp. In a village model hut. Indian Fd. Packer. 33(6): 9-25.

Bhatti, M.A., Mir, F.A. and Siddiq, M. 1987. Effect of different bedding materials on relative yield of oyster mushroom in the successive flushes. Pakistan J. Agril. Res 8(3): 256-259.

Bugarski, D., Gvozdenovic, D., Takae, A. and Cervenski, J. 1994. Yield and yield components of different strains of oyster mushroom. Savremena poljoprivreda (Yugoslavia). 42 (1): 314-318.

Chang, S.T. and Miles, P.G. 1988. Edible Mushroom and their cultivation. CRC press, Inc. Boca Raton, Florida U.S.A.27:83-88.

Chow, L.P. 1980. Utilization of cotton waste substrate with temperature treatment for cultivation of oyster mushroom in Singapore, Singapore J. Pri. Ind. 8(10: 21-27).

Gohl, G. 1993. Tropical Feeds. Published by Food and Agriculture Organization of United Nation. Revised by Andrew speedy computer journal version-4.

Gomez, K.A. and Gomez, A.A. 1984. Statistical procedure for Agricultural research. $2^{\text {nd }}$ edition. John Wiley and Sons, New York. 680P $\mathrm{p}$.

Kitamoto, Y., Horkoshi, T., Hosio, N. and Ichikawa, Y. 1995. Nutritional study of fruiting-body formation in Psilocybe panaeoliformis. Trans. Mycol. Soc. (Japan). 16(3): 268.

Mueller, M. and Cantner, E.W. 1990. Mushroom cultivation for feed and food. Entwicklung-und-laendlicher-Raum (Germany, F.R.). 22(2) 15-17.

Obodai, M., Kine, J.C.O. and Vowotor, K.A. 2003. Comparative study on the growth and yield of Pleurotus ostreatus mushroom on different lignocellulosic by products. J. Indian Microbial. Biotechnol. 30(3):146-149.

Poppe, J.A. 1973. The fruit regulating action of light and chemicals in the culture of $P$. spp (Fr.) Medeligen, Vande Paculteit Land bouwweten sheappen. 38(3): 1387-1397, (cited from Hort. Abst. 44(2): 1974-9737).

Quimio, T.H. 1980. Survey and culture of edible ones, In: cultivation of edible mushroom in tropics, UNESCO, Regional workshop, Manila. 
Quimio, T.H. and Sardsud, U. 1981. Nutritional requirements of Pleurotus ostreatus (Fr). Philippine Agriculturist. 64(1): 79-89.

Shah, Z. A., Ashraf and Ishtiaq, M.C. 2004. Comparative study on cultivation and yield performance of Oyster mushroom (Pleurotus ostreatus) on different substrates (wheat straw, Leaves and Sawdust). Pakistan J. Nutrition. 3(3): 158-160

Tan, K.K. 1981. Cotton waste is a fungus (Pleurotus) good substrates for cultivation of Pleurotus ostreatus, the Oyster mushroom. Mushroom Sci. 11: 705-710

Wang, C.W. 1982. Cellulolytacenzymes of Volvariella Volvacea Tropical Mushrooms Biological Nature and cultivation methods (ed.) S.T. Chang and T.H. Quimio, The Chinese University press, Hongkong.

Zhang, R.H., Li, X.J. and Fadel, J.G. 2002. Oyster mushroom cultivation with rice and wheat straw. Bioresour. Technol. 82(3): 277284.

Zadrazil, F. 1978. Cultivation of Pleurotus. The biology and cultivation of edible mushrooms by S.T. Chang and W.A. Hayes (eds). Academic press INC. Orlando, Florida. 1:62. 